\title{
Bioremediation in Antarctic Soils
}

Hugo E de Jesus, Raquel S Peixoto and Alexandre S Rosado*

Molecular Microbial Ecology Laboratory, IMPG/Universidade Federal do Rio de Janeiro, Rio de Janeiro, Brazil

\begin{abstract}
With the increase in human activities in cold environments, the risk of an oil spill has become higher due to the necessity of using oils to generate energy. Several accidents have occurred in the Arctic and Antarctic involving severely contaminated areas and chronic levels of contamination. In the Antarctic, the main occupations are permanent scientific and military stations, most of which are active throughout the year. Several studies evaluating the potential for biodegradation were performed using Antarctic soils, and the results were promising; however, there are no studies on the bioremediation process in soils from the core of the continent, only from the shore regions. The Antarctic continent contains a diverse microbial community that can degrade oils even under extreme conditions. In this regard, bioremediation treatments are indicated to promote a sustainable, low-cost and efficient recovery process that must be performed as soon as possible after the spill to improve this efficiency. This paper provides an unprecedented review of the bioremediation process exclusive to Antarctic soils; provides the necessary knowledge for consolidating the bioremediation process in the Antarctic environment; and suggests strategies for applying these techniques.
\end{abstract}

Keywords: Bioremediation; Antarctic environments; Antarctica; Soil

\section{Introduction}

Bioremediation has been considered a method for promoting the recuperation of contaminated environments at both higher and lower temperatures for at least four decades [1,2]. Biodegradation by microorganisms appears to be the most efficient and economically viable method that poses the lowest risk to the environment compared with other approaches [3-5]. Biodegradation techniques focus on utilizing natural biological activity to decrease toxic pollutant concentrations [6].

The bioremediation of petroleum hydrocarbons has been widely studied in different environments to build knowledge regarding biodegradation and the possible consequences after an oil spill. Several studies in the literature have shown that after an oil spill, various important processes may occur, including sorption, the abiotic processing of volatilization (chemical or photochemical), bioaccumulation and absorption by soil particles and biotransformation [7]. The effect and efficiency of hydrocarbon degradation depends on several factors, including temperature, bioavailability, access to microbial cells, metabolic limitations, oxygen, alternate electron acceptors, nutrients and toxicity [3]. However, despite the accumulated knowledge about biodegradation, the study of bioremediation in an Antarctic environment is minimal because the challenging conditions found in this continent alter and promote the rearrangement of all of the important factors [3].

Because of the geographic isolation and difficult life conditions, the Antarctic continent remained without human intervention until the XX century [8]. Even today, the continent is used primarily as a research resource, and many research stations have thus been built in different regions to host researchers from various research areas (Figure 1). This occupation began in 1958 due to the International Geophysical Year; since then, fifty-five research stations have been built and are now occupied by more than five thousand people [8].

The annual human activities on the continent demand basic conditions such as energy generation, and oils of fossil origin are frequently used to supply this energy. Both exploration and the transport and storage of fuel oil promote increased accident risks [9].
Fuel oil spills are among the main sources of contamination caused directly by humans in the Antarctic environment [8]. The fuels and oils consist of alkanes and polyaromatic hydrocarbons (HPA) that are persistent in the environment $[10,11]$ and have mutagenic, toxic and carcinogenic effects [12]. However, the main oil blends used in the Antarctic, which are, consequently, the most present in chronic contaminations across the continent, consist primarily of C9-C14 aliphatic hydrocarbons $[13,14]$. According to previous research, the cold environment can be more severely affected by contaminants than other environments, even at the same contamination level, because the necessary cold adaptions make these environments more sensitive [15].

There are many chronically contaminated sites near research stations [16], and some studies have already reported high contamination levels near McMurdo Station (USA Antarctic station) $[17,18]$. These high levels of contamination probably occurred when there was no regulation of the treatment of generated waste [19], and the difficult environmental conditions combined with low evaporation, photo-oxidation, low humidity and nutritional limitations led to the persistence of those compounds for decades after the spill [16,20,21]. Now, all research stations built in the Antarctic should treat their waste and take care to avoid environmental contamination in accordance with the Antarctic treaty [22]. However, there are still no overall guidelines in the case of future contamination in Antarctica [23].

Over the last few years, the bioremediation applied and studied in the Antarctic has been linked to Arctic bioremediation due to the low temperatures in both climates. However, we realize that there are many special features that require additional analysis, and additional

*Corresponding author: Alexandre S Rosado, LEMM - Laboratório de Ecologia MicrobianaMolecular-InstitutodeMicrobiologiaPaulodeGóes(IMPG)-Universidade Federal do Rio de Janeiro, Rio de Janeiro, Brazil, Tel: 5521 2562-6740; E-mail: asrosado@micro.ufrj.br

Received May 29, 2015; Accepted July 16, 2015; Published July 26, 2015

Citation: Jesus HE, Peixoto RS, Rosado AS (2015) Bioremediation in Antarctic Soils. J Pet Environ Biotechnol 6: 248. doi:10.4172/2157-7463.1000248

Copyright: (C) 2015 Jesus HE, et al. This is an open-access article distributed under the terms of the Creative Commons Attribution License, which permits unrestricted use, distribution, and reproduction in any medium, provided the original author and source are credited. 
considerations must be accounted for to help improve the knowledge of bioremediation in the Antarctic environment. To date, knowledge regarding emergency procedures in the Antarctic continent is scarce, and there is no strategy to be followed after accidental spills [3].

\section{Environmental Factors and Bioremediation Techniques Applied}

The Antarctic continent is defined as all landmass, ice shelves and sea in the area below $60^{\circ} \mathrm{S}$ [23]. The continent can be divided into two large areas based on climatic and biotic features. The first comprises the Antarctic Maritime, including South Sandwich island, Bouvetoya island, South Orkney island, South Shetland island and the area east of the Antarctic Peninsula. The second comprises the Continental Antarctic, including the area west of the Antarctic Peninsula and the rest of the continent [24]. In these regions, environmental conditions are driven by topology, altitude and sea proximity. For example, the soil $\mathrm{pH}$ can vary dramatically depending on the origin material [25].

One of the harshest Antarctic environments is a region called the McMurdo Dry Valleys. This region is located between the Polar Plateau and the Ross Sea in Southern Victoria Land [26] and is characterized by a large temperature variation. The annual means are between $-15^{\circ}$ and $-30^{\circ} \mathrm{C}$, but the surface soil temperature can exceed $0^{\circ} \mathrm{C}$ in the summer [27]. Mineral soil is present in ice-free areas, and this region exhibits the most "dry" environment in relation to nutrients, water and energy [26]. Because of these difficult conditions, research in this area is rare and occurs primarily in tents; consequently, the impacts generated are lower, but great care is needed in the future because the environmental conditions make the recovery process through biodegradation very difficult.

The best region for successful bioremediation in the Antarctic is the Maritime Antarctic. In this region, temperatures above $0^{\circ} \mathrm{C}$ are common in the summer, as at King George island. However, in the Antarctic, the $\mathrm{pH}$ ranges from 6 on the island to 9 on the shore [16], and soils with $\mathrm{pH}$ levels over 8.8 have been shown to exhibit more efficient hydrocarbon biodegradation $[10,28]$. This difference in the $\mathrm{pH}$ range is due to the proximity to the sea, which results in an increased influence of the sea currents from the tropics [29]. Many research stations are in this region, and a considerable ship flux crosses it, carrying food, vehicles, tourists and fuel [30].

Temperature is among the most important factors in determining the success of biodegradation for many reasons. Microorganisms need an ideal temperature, normally from 15 to $30^{\circ} \mathrm{C}$ in aerobic conditions and 25 to $35^{\circ} \mathrm{C}$ for anaerobic processes [31], to metabolize their substrates and thus promote their elimination. Low temperatures make this process difficult because the microbial metabolism decreases at lower temperature, and the biodegradation taxa consequently decrease as well [32]. Additionally, low temperatures increase oil viscosity, reduce evaporation and increase water solubility, delaying the biodegradation process [33,34]. Because of these cited factors, bioremediation treatments are indicated in summertime, when the temperatures are higher, the soils are unfrozen and water is available [20]. However, in the case of spills, low temperatures can be used positively because snow can contain the contamination as a containment boom and slow the penetration of the spilled oil by acting as an absorbent material [3].

Bioremediation treatment under aerobic conditions is more efficient than under anaerobic conditions because the major degradation pathways involved in the aerobic hydrocarbon degradation process generate more energy and consequently occur faster [3]. Nearly $0.3 \mathrm{~g}$ of oxygen is necessary for each gram of oil oxidized [35]. Therefore, oxygen limitation could be among the main causes of bioremediation failure. The Antarctic continent is generally well aerated throughout the year by strong winds [27], and the soil has high granulometry [26], which facilitates aeration. The microbial community, which can promote biodegradation through aerobiosis, should also be able to internalize the substrate once the general biodegradation of chemicals occurs inside the cell [3].

This contact and capacity of microbial cells to internalize a substrate is called bioavailability, and it is crucial for the biodegradation process. In environments with temperatures lower than the freezing point, the channels across the cell membrane may close, and the cytoplasmic matrix can freeze, thus halting the cell functionality [36]. The aqueous solubility of a contaminant correlates inversely with adsorption, which is another factor that can disturb the bioavailability [37], because when the contaminant is absorbed by organic soils, its bioavailability decreases, and biodegradation tends to stop. In that situation, previous research has suggested that cold-active solubilizing agents could be a good option to solve this problem [33], such as the bioemulsifiers produced from the bacterial strains [38,39]. In the Antarctic continent, some of the organic soils are called ornithogenic soils; they are important for the presence of penguins and have special characteristics such as acidic $\mathrm{pH}$ and higher nutrient levels [16].

In the bioremediation process, nutrients and organic compounds are important as carbon sources or electron donors, and inorganic nutrients such as cations, nitrates and phosphates are also needed [3]. When a spill occurs, the carbon:nitrogen:phosphate (C:N:P) ratio in the soil tends to become unbalanced, and a rapid depletion of nitrogen and phosphorus often occurs, making these two compounds limiting factors [40]. However, Antarctic soils are generally poor in nutrients $[16,41]$, which can halt degradation. In that case, the addition of fertilizer could solve the problem and supply the necessary nutrients to promote the process. In Antarctic environments, the freeze-thaw cycles are frequent every year and should be considered when adding fertilizer to the soil because the unfrozen water flux tends to disturb the nutrient distribution and unbalance the C:N:P ratio again. Fertilizer supplementation should be performed with care because excessive nitrogen levels may result in an inhibition of microbial activity [42]. Large amounts of contaminants can also inhibit biodegradation when the concentration is above the toxic threshold [37]; in this case, bioremediation should not be implemented without the prior use of physical removal methods.

\section{Application}

Bioremediation treatments can be classified into two categories: in situ and ex situ. In situ treatments are characterized by avoiding the removal of contaminated material from the site where the recovery is performed. In ex situ treatments, the contaminated material is removed, treated, decontaminated, and subsequently returned to the site where the contamination occurred. Due to the inability to transport contaminated Antarctic soil, in situ treatments are more indicated. Among such treatments, biostimulation and bioaugmentation are the two techniques most cited in the literature $[6,43,44]$.

Biostimulation consists of adding nutrients to the soil and to maximize the biodegradation by balancing the $\mathrm{C}: \mathrm{N}: \mathrm{P}$ ratio, which is very important for achieving an ideal nutrient concentration and consequently efficient remediation with less cost [45]. This technique also aims to adjust the $\mathrm{pH}$ and correct the moisture and aeration [46], thus promoting and increasing the ability of indigenous microorganisms to degrade the pollutant [47]. This technique is among 


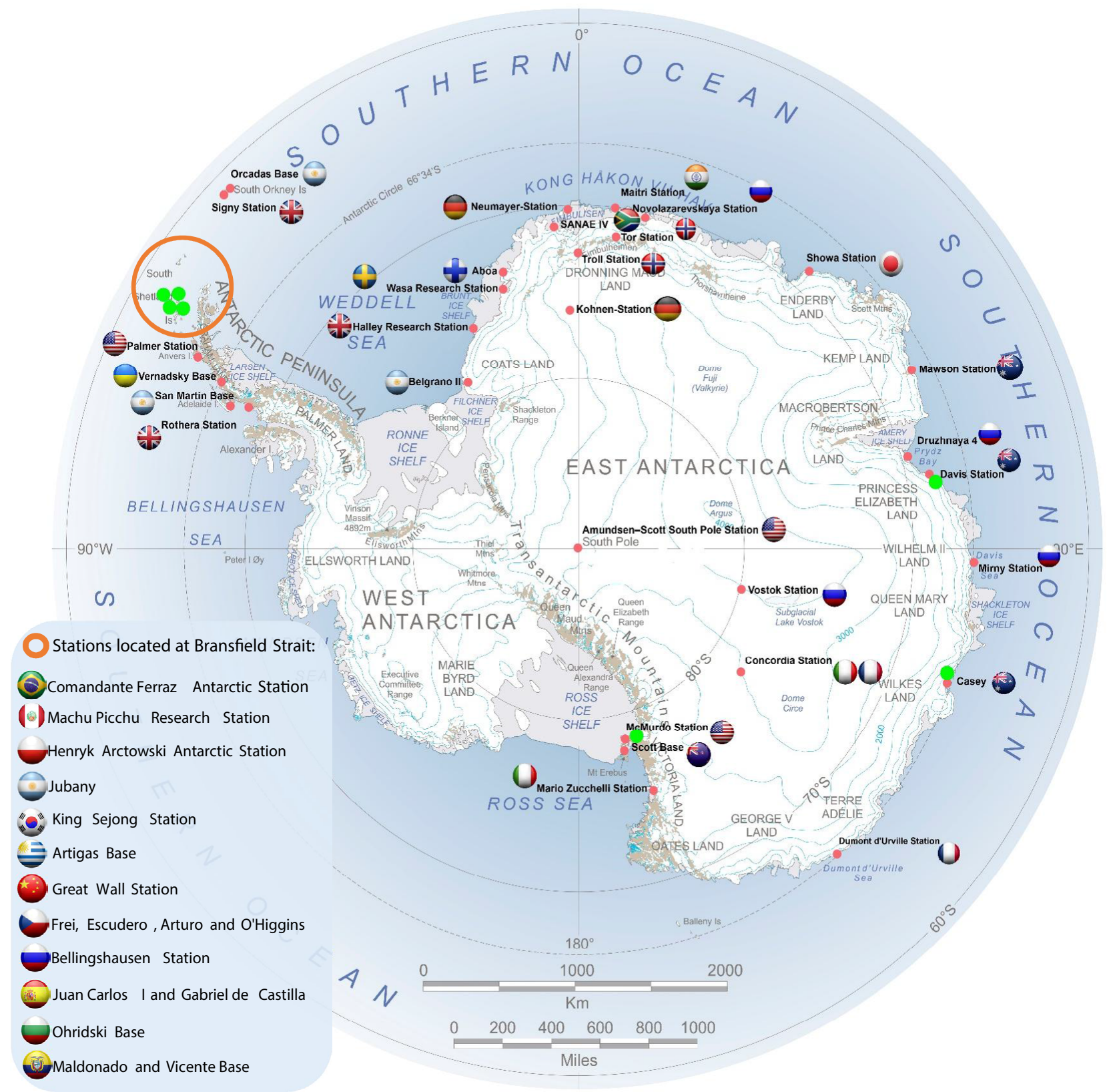

Figure 1: Map of the Antarctic Continent showing the locations of permanent and semi-permanent Antarctic Stations of each country (red circles) and of in situ bioremediation treatments conducted (green circles). Map adapted from http://lima.usgs.gov and station locations provided by the COMNAP Antarctic Facilities Map (HYPERLINK “http://www.comnap.aq” It “_blank” www.comnap.aq).

the most strongly indicated to promote soil recovery in the Antarctic because we know that microbial communities exist in Antarctic soils and are able to degrade hydrocarbons [21,48]. The application of biostimulation to Antarctic soil has been described for some time, and the mineralization of alkanes has already been shown, using the addition of nitrogen to the soil in the forms of nitrate and ammonium [10]. Biostimulation was successfully performed in sub-Antarctic regions, and the soil properties had a great influence on the process [49]. According to this study, biostimulation presented better results when applied in mineral soil than in organic soil for both types of oil used (crude oil and diesel oil). Furthermore, the temperature was also important, as the degradation levels ranged from $76 \%$ to $96 \%$ at soil temperatures of 4 and $20^{\circ} \mathrm{C}$, respectively.
In the case of low abundance or low metabolic activity of indigenous hydrocarbon-degrading microorganisms (e.g., due to lower temperature), the addition of microorganisms that were previously isolated in the laboratory and are known to be able to degrade the compound of interest can be used to improve biodegradation $[42,50,51]$. This technique, called bioaugmentation, aims to maintain a high microbial biomass [44]. In this regard, native and non-native species could be used, but indigenous species are preferred to reduce the environmental impact [52]. In accordance with the Antarctic treaty norms, the introduction of strange biological material is not permitted. During bioaugmentation, the possibility of total mineralization increases when a microbial consortium is used instead of only one organism $r[53,54]$. This increase is because normally, the 
contaminant has several fractions, and each microorganism is able to degrade a specific fraction [55]. However, it is necessary to perform tests to evaluate environmental conditions, soil features, predation and competitive effects that cannot be inferred in advance [56]. For this purpose, successful degradation by a microbial consortium in a microcosm experiment using contaminated soil from a site near the fuel tanks located close to the Argentine Antarctic research station (King George island) has already been reported [42].

A previous study demonstrated the efficiency of bioremediation in a microcosm experiment at $4^{\circ} \mathrm{C}$, using pristine soil from Signy Island with experimental contamination. In this study, the addition of nutrients enhanced the hydrocarbon biodegradation process faster than hydration treatment alone, but the stronger degradation rate slowed after seven days. However, biostimulation plus bioaugmentation treatment resulted in a faster degradation rate than all of the other treatments separately [60] due to an increase in the proportion of microbial organisms that could degrade the substrate in the initial stages [61]. This difference led to a rapid degradation a few weeks after the beginning of the experiment, although both biostimulation treatments reached $100 \%$ degradation after 18 weeks [60]. Based on the obtained results, the authors suggest bioaugmentation with native microbiota to increase the rate of degradation during the period immediately following oil spills.

Despite the common knowledge of the presence of microorganisms able to degrade hydrocarbons in soils and thus promote natural attenuation [52,62,63], old fuel spill areas near Casey Station were analyzed, and the results demonstrated that although large amounts of the contaminant were eliminated by evaporation, natural attenuation is not sufficient to prevent the contaminant migration to areas that are more sensitive. Thus, this technique is not suitable for the management of fuel spills in the Antarctic region [64].

Although many studies have reported the efficiency of fertilizer addition in Antarctic soils, it is worth noting that the concentration of nutrients should be considered based on the contamination level. Along these lines, a recent study demonstrated that for soils with lower contamination, the ideal fertilizer concentration to promote the highest degradation levels was $125 \mathrm{mg} \mathrm{N} \mathrm{kg-1}$ of soil, whereas in more contaminated soil, the concentration that promoted the best result ranged from 200-500 mg N kg-1 [65]. This result reinforces the need to study the area to be treated and thus apply the appropriate treatment.

\section{Isolation and Cultivation}

Microorganisms able to degrade petroleum hydrocarbons are widely distributed in Antarctic soils [16]. In places where the addition of a microbial consortium is needed to increase the microbial biomass and improve degradation rates, prior isolation and characterization of the organisms to be used is required. Furthermore, it is important to know all possible information about the microbial communities that are present at the studied site. Therefore, conventional tools, including isolation and characterization, are very important. Despite the limitations imposed by cultivation [66,67], several strains are being isolated from the Antarctic soil with a great capacity to degrade hydrocarbons $[57,60]$.

\section{Main Groups Found}

Among the bacterial strains that have been isolated from the Antarctic continent, Rhodococcus is among the most highly reported as a significant part of the soil communities and is recognized for its great metabolic potential [69]. This bacterial genus was able to degrade alkanes with chain lengths from C6 to C20, known as persistent fractions in Antarctic soils [10], as well as aromatic compounds [70]. Despite their slow growth, these bacteria have good substrate affinity and persistence in the environment [69], which suggests that they may be successfully used in the Antarctic bioremediation process. Although they can adapt to sub-zero temperatures, their ideal growth temperature is above $15^{\circ} \mathrm{C}$ [71]. Similar Rhodococcus strains seem to be found in different types of contaminated Antarctic soils, suggesting that their presence is linked to the presence of contamination and not to the type of soil [57,71].

The Acinetobacter genus has been reported as another important hydrocarbon degrader in Antarctic soil [16,72]. The strain Acinetobacter B-2-2 was used together with a Rhodococcus ADH strain in a microcosm experiment [57] and was able to degrade $81.1 \%$ of the oil in a pristine soil contaminated for the experiment, compared with the 75\% degradation obtained by the strain Acinetobacter B-2-2 used alone in a previous study [42]. When the Rhodococcus ADH strain was used alone, a decline occurred in the number of bacteria, but this decline did not occur when both strains were used together. These data suggest that the decline could be caused by an incompletely oxidized compound with toxic effects [73], but when both strains were used together, they could use different catabolic pathways and thus generate a synergistic cooperation whereby the toxic compounds produced by one strain were consumed by the other [57]. In this regard, the authors suggest that when a spill occurs in pristine Antarctic soil, a bioaugmentation process might be adequate to promote fast degradation. In chronically contaminated soils, however, the bacterial flora has been enhanced by long-term exposure to the pollutant, and thus it is not necessary to add new organisms for degradation.

Bacteria from the Pseudomonas genus are known as one of the major hydrocarbon-degrading groups [74]. They are recognized as highly efficient hydrocarbon-degrading, cold-adapted bacteria [75], and many studies have found this bacterial group in contaminated Antarctic soil $[9,76,77]$. Although many studies have shown that degradation is unfavorable at oil concentrations over $1.5 \%[78,79]$ and that high oil concentrations can be toxic to microorganisms [74], Pseudomonas sp. J3 isolated from the Antarctic Peninsula showed great cellular growth after 6 days in the presence of $3.5 \%$ diesel oil $(\mathrm{v} / \mathrm{v})$. The temperature used ranged from $10-15^{\circ} \mathrm{C}$, and the $\mathrm{pH}$ was 7 [74]. In another study aimed at identifying native Antarctic soil bacterial strains that are capable of degrading oil at low temperatures, Pseudomonas ST41 strain, isolated from a pristine soil and grown on a wide range of hydrocarbons (aliphatic and aromatic), showed a better degradation level at $4^{\circ} \mathrm{C}$. In this study, the Pseudomonas group was dominant in both biostimulation and bioaugmentation microcosms.

Another bacterial group isolated from Antarctic environments that has been shown to be capable of using hydrocarbons as a unique carbon source is Sphingomonas [16,77]. The strain Ant 17, isolated from Scott Base-Antarctic, was able to degrade the aromatic fraction of several different crude oils at a low temperatures ranging from 1 to $35^{\circ} \mathrm{C}$, but the best condition was $\mathrm{pH} 6.4$ at $22^{\circ} \mathrm{C}$. Additionally, Sphingomonas Ant 17 displayed tolerance to UV irradiation and freeze-thaw cycles [80], which is very useful in Antarctic environments that are subjected to these conditions frequently. The presence of genes responsible for the degradation ability of Sphingomonas has been reported in both plasmid and chromosomal locations [81], but because strain Ant 17 seems to have no plasmids, its aromatic degradation ability must be linked to a chromosomal gene. This genetic structure is a positive 
aspect of this strain, as the chromosomal location provides greater genetic stability [80].

Bacterial strains of the Rhodococcus, Sphingomonas, Pseudomonas and Acinetobacter genera were indicated as the main hydrocarbondegrading groups present in Antarctic soil $[9,82]$. These bacterial groups have been used in different studies in Antarctic environments, ranging from isolation and classification to in situ application experiments (Table 1). However, recent data on the potential hydrocarbon-degrading bacterial consortium from Antarctic soils indicated that the Pseudomonas genus was the most frequent, followed by Stenotrophomonas and two low-abundance genera, Pedobacter and Brevundimonas [13].

\section{Quantification of Hydrocarbon - Degrading Microorganisms}

Quantification of microbial cell using Most Probable Number (MPN) and Colony forming Unit (CFU) techniques have been used to estimate the number of total heterotrophics and total hydrocarbondegrading microorganisms [60-70]. Utilizing MPN Cury and colleagues [30] found great amount of total heterotrophic aerobic bacteria (HAB) in soils with higher and lower oil concentration $\left(\geq 1.1 .10^{8}\right.$ cells $\left.\mathrm{g}^{-1}\right)$ but there was no relationship between oils concentration and number of hydrocarbon-degrading bacteria (HDB), once the values varied to all samples. The same happened to another MNP experiment using total heterotrophic cells when after four years since application of fertilizer, in higher and lower oil concentrations, the results were very variable and did show significance [77].

Differently, the number of HDB increased after addition of both crude and diesel oil even after 330 experimental days [66] and also after 51 experiment assay using contaminated soil plus bioaugmentation when HDB number increased [88]. Lastly, Ruberto and colleagues [10] reported increased in $\mathrm{HDB}$ and $\mathrm{HAB}$ number, as well as to $\mathrm{HDB} / \mathrm{HAB}$ ratio in microcosms experiment with contaminated soil plus nutrients or bacterial strains. In the end of experiment time, the authors reported a diminution in level of $\mathrm{HDB}, \mathrm{HAB}, \mathrm{HDB} / \mathrm{HAB}$ rate and also in the total hydrocarbon concentration, suggesting the initial steps of soil recovery process.

\section{Molecular Tools}

The Most Probable Number (MPN) and Colony Forming Unit (CFU) techniques for the quantification of microbial cells have been used to estimate the number of total heterotrophics and total hydrocarbondegrading microorganisms $[42,57,65,83,84]$. Utilizing MPN, a previous study found a great amount of total heterotrophic aerobic bacteria (HAB) in soils with higher and lower oil concentrations ( $\geq 1.1 .108$ cells g-1), but there was no relationship between the oil concentration and the number of hydrocarbon-degrading bacteria (HDB) because the values varied for all samples [65]. Similar results were obtained from another MPN experiment using total heterotrophic cells, where the researchers evaluated the application of fertilizer under higher and lower oil concentrations for four years; the results were highly variable but did not show significance [83].

In contrast, the number of HDB increased after the addition of both crude and diesel oil, even after 330 experimental days [84], and after 51 days of an experimental assay using contaminated soil plus bioaugmentation, the HDB number increased significantly [57]. Finally, an increase in $\mathrm{HDB}$ and $\mathrm{HAB}$ numbers was reported in addition to an increased $\mathrm{HDB} / \mathrm{HAB}$ ratio in a microcosm experiment with contaminated soil plus nutrients or bacterial strains. At the end of the experiment, the authors reported a diminution in the levels of $\mathrm{HDB}$ and $\mathrm{HAB}$, the $\mathrm{HDB} / \mathrm{HAB}$ ratio and the total hydrocarbon concentration, thus suggesting the initial steps of the soil recovery process.

\section{Molecular detection, fingerprint and sequencing}

The Deinococcus-Thermus and Gemmatimonadetes clades are common in the Dry Valley based on clone library studies, whereas in other surface soils, they have no representation [26]. This difference could be directly related to the fact that Deinococcus-Thermus is known for its ability to resist high levels of ultraviolet (UV) radiation [91], which is very useful in the Dry Valley because that region has a high incidence of solar radiation with an elevated ultraviolet (UV) light component $[92,93]$. Gemmatimonadetes is a rarely cultivated microorganism, and its characteristics are not yet well clarified [94]. As cited previously, Pseudomonas, Acinetobacter, Sphingomonas (Proteobacteria phylum) and Rhodococcus (Actinobacteria phylum) are among the main hydrocarbon-degrading bacteria groups reported in the literature, but due to the great difference between the microbial profiles of the Dry Valley and the Antarctic Peninsula, the microbial dynamics involved in the biodegradation process at Dry Valley may be completely different.

The 16S rRNA gene was analyzed using a T-RFLP technique to elucidate the profile changes in a microcosm experiment, and a rapid response from the bacterial community to the treatment applied was observed [19]. These results revealed the ability of the bacteria to rapidly respond in previously contaminated Antarctic soil and to metabolize nutrients added to the soil when aeration and a carbon source are available [19]. In this study, biostimulation and bioaugmentation were tested, but the microbial consortium used was not able to survive for the entire experiment, which likely contributed to the lack of a significant difference between the treatments. After 60 days of experimentation in a microcosm, DGGE analyses revealed different clusters between soils with higher and lower hydrocarbon concentrations. Additionally, the results demonstrated the effects of different concentrations of fertilizer on the prokaryotic community [65].

A biopile experiment was assembled at Carlini Argentinean Scientific Station, and a 16S rRNA PCR-DGGE technique showed no difference between the biostimulation treatment (FM) and the control (CC) in the first 5 days, but on the 50th day of experimentation, the difference in the profile was dramatic [58]. The difference in the response time might be related to the experimental dimensions and consequently to the availability of oxygen, water and nutrients. The DGGE bands extracted revealed that $53 \%$ of the bacteria belonged to the Proteobacteria phylum. At the 50th day, $20 \%$ of the sequenced bands belonged to the Actinobacteria phylum and were only present in the biostimulation treatment condition (FM) [58]. The same technique was used to demonstrate the high-diversity bacterial fingerprint in disturbed and non-disturbed soils around the Japanese Antarctic Station at East Ongul Island [95]. This study identified the sequences from the dominant bands as belonging to the Sphingomonas, Porphyrobacter, and Methylobacter groups. DGGE and T-RFLP were also used to demonstrate the presence of a hydrocarbon-degrading bacterial consortium at the end of the experiment [13].

Soil samples from hydrocarbon-polluted and pristine soils from King George island were analyzed using DGGE and RFLP techniques, with the alkane monooxygenase alkB gene as a target, and the generated fingerprints showed the formation of clusters in contaminated vs. 


\begin{tabular}{|c|c|c|c|c|c|c|}
\hline Strain & Culture medium & $\begin{array}{l}\text { Incubation (temp/ } \\
\text { period) }\end{array}$ & Substrates degraded & $\begin{array}{l}\text { Substrate } \\
\text { concentration }\end{array}$ & Isolation place & References \\
\hline Acinetobacter B-2-2 & Soil & $\begin{array}{l}\text { avarege } 2.5^{\circ} \mathrm{C} / 51 \\
\text { days }\end{array}$ & gas-oil & $1.5 \%$ & $\begin{array}{l}\text { Jubany scientifc station }(62 \cdot 14 \text { 'S; } \\
\left.588^{\circ} 40^{\prime} \mathrm{W}\right)\end{array}$ & [84] \\
\hline Sphingomonas Ant17 & Mineral medium (MM) & $10^{\circ} \mathrm{C} / 4-8$ weeks & Crude oil & $1.5 \%$ & Scott Base-Ross Island -N/A & [26] \\
\hline Sphingomonas $43 / 17$ & Bushenell Has (BH) & $15^{\circ} \mathrm{C} / 3$ weeks & Phenanthrene & $1.5 \%$ & $\begin{array}{l}\text { Scott Base-Ross Island -N/A } \\
\left.\text { (S77 } 50^{\prime} 53.90^{\prime \prime} ; \text { E } 166^{\circ} 45^{\prime} 40.70^{\prime \prime}\right)\end{array}$ & {$[86]$} \\
\hline Sphingomonas Ant 17 & Bushenell Has (BH) & $16^{\circ} \mathrm{C} /$ up to 1 month & $\begin{array}{l}\text { JP-8; m-xylene; 1-methyl } \\
\text { naphthalene; 2-methyl } \\
\text { naphthalene;phenantrene; } \\
\text { fluorene; heptane; } \\
\text { undecane; dodecane }\end{array}$ & vapour & Scott Base -N/A & [20] \\
\hline Rhodococcus $4 / 38$ & Bushenell Has $(\mathrm{BH})$ & $16^{\circ} \mathrm{C} / 7$ days & $\begin{array}{l}\text { C6, C8, C11, C12, C13, C16, } \\
\text { C20, C12-1, Pristane }\end{array}$ & $0.5 \%$ & Scott Base -N/A & [27] \\
\hline Rhodococcus 8/1 & Bushenell Has $(\mathrm{BH})$ & $16^{\circ} \mathrm{C} / 7$ days & $\begin{array}{l}\text { C6, C8, C11, C12, C13, C16, } \\
\text { C20, C12-1, Pristane }\end{array}$ & $0.5 \%$ & Scott Base -N/A & [27] \\
\hline Rhodococcus $8 / 5$ & Bushenell Has $(\mathrm{BH})$ & $16^{\circ} \mathrm{C} / 7$ days & $\begin{array}{l}\text { C6, C8, C11, C12, C13, C16, } \\
\text { C20, C12-1, Pristane }\end{array}$ & $0.5 \%$ & Scott Base -N/A & [27] \\
\hline Rhodococcus ADH & Soil & $\begin{array}{l}\text { avarege } 2.5^{\circ} \mathrm{C} / 51 \\
\text { days }\end{array}$ & Diesel oil & $0.5 \%$ & $\begin{array}{l}\text { Jubany scientifc station }(62 \cdot 14 \text { 'S; } \\
\left.588^{\circ} 40^{\prime} \mathrm{W}\right)\end{array}$ & [81] \\
\hline Rhodococcus $43 / 2$ & $\begin{array}{l}\text { Bushenell Has (BH; } \\
\text { Difco) }\end{array}$ & $15^{\circ} \mathrm{C} / 3$ weeks & $\begin{array}{l}\text { C12-dodecane,C16- } \\
\text { hexadecane, Pristane, JP5 } \\
\text { jet fuel }\end{array}$ & $0.5 \%$ & $\begin{array}{l}\text { Scott Base-Ross Island (S77 } \\
\left.\text { 50'53.90"; E166 } 45^{\prime} 40.70^{\prime \prime}\right)\end{array}$ & [86] \\
\hline Pseudomonas ST41 & Mineral Medium (MM) & $4^{\circ} \mathrm{C} / \mathrm{up}$ to 2 months & Polar Blend marine gas oil & $0.2 \%+$ vapour & $\begin{array}{l}\text { South Orkney Islands }\left(60^{\circ} 45^{\prime} \mathrm{S} \text {, }\right. \\
\left.45^{\circ} 36^{\prime} \mathrm{W}\right)\end{array}$ & [95] \\
\hline Pseudomonas J3 & basalt salt media & $10^{\circ} \mathrm{C} / 10$ days & Diesel soil & $0.5 \%$ & Jubany Station $\left(61.5^{\circ} \mathrm{S} 54.55^{\circ} \mathrm{W}\right)$ & [87] \\
\hline Pseudomonas 5B & N-deficient (NDS) & $22^{\circ} \mathrm{C} / 10$ days & JP-8 jet fuel & vapour & Marble Point $-\mathrm{N} / \mathrm{A}$ & [45] \\
\hline Pseudomonas $44 / 47$ & Bushenell Has (BH) & $15^{\circ} \mathrm{C} / 3$ weeks & $\begin{array}{l}\text { C12,C16, Pristane, Toluene, } \\
\text { JP5 jet fuel }\end{array}$ & $0.5 \%$ & $\begin{array}{l}\text { Scott Base-Ross Island (S77 } \\
\left.\text { 50'53.90"; E166 } 45^{\circ} 40.70^{\prime \prime}\right)\end{array}$ & {$[86]$} \\
\hline Pseudomonas Ant 9 & Bushenell Has (BH) & $16^{\circ} \mathrm{C} /$ up to 1 month & $\begin{array}{l}\text { JP-8; p-xylene; 1,2,4-trimethyl } \\
\text { benzene; naphthalene; } \\
\text { 2-methyl naphthalene }\end{array}$ & vapour & Scott Base -N/A & [19] \\
\hline Pseudomonas Ant 30 & Bushenell Has (BH) & $16^{\circ} \mathrm{C} /$ up to 1 month & $\begin{array}{l}\text { JP-8; toluene; m-xylene; } \\
\text { p-xylene; 1,2,4-trimethyl } \\
\text { benzene; heptane; undecane }\end{array}$ & vapour & Scott Base -N/A & [19] \\
\hline Pseudomonas Ant 7/22 & Bushenell Has (BH) & $16^{\circ} \mathrm{C} /$ up to 1 month & $\begin{array}{l}\text { JP-8; toluene; m-xylene; } \\
\text { p-xylene; 1,2,4-trimethyl } \\
\text { benzene }\end{array}$ & vapour & Scott Base -N/A & [19] \\
\hline Pseudomonas DRYJ7 & Basal médium & $10^{\circ} \mathrm{C} / 4$ days & acrylamide & $0.1 \%$ & Casey Station $\left(66.17^{\circ} \mathrm{S} 110.32^{\circ} \mathrm{E}\right)$ & [87] \\
\hline $\begin{array}{l}\text { Pseudomonas LCY12 } \\
\text { and LCY16 }\end{array}$ & Mineral medium (MM) & $4-40^{\circ} \mathrm{C} / \mathrm{N} / \mathrm{A}$ & $\begin{array}{l}\text { naphthalene and } \\
\text { phenanthrene }\end{array}$ & $0.15 \%$ & $\begin{array}{l}\text { Great Wall station } \\
\left(65^{\circ} 12^{\prime} 59^{\prime \prime} \mathrm{S} / 58^{\circ} 57^{\prime} 05^{\prime \prime} \mathrm{W}\right)\end{array}$ & [65] \\
\hline $\begin{array}{l}\text { Pseudomonas sp. } \\
\text { FG-15 }\end{array}$ & SBM & $15^{\circ} \mathrm{C} / 15$ days & $\begin{array}{l}\text { Pyrene; Toluene; Octane; } \\
\text { Dodecane }\end{array}$ & $0.1-1 \%$ & Marambio $\left(64^{\circ} 14^{\prime} \mathrm{S}, 56^{\circ} 37^{\prime} \mathrm{W}\right)$ & {$[100]$} \\
\hline $\begin{array}{l}\text { Pseudomonas sp. } \\
\text { FG-4a }\end{array}$ & SBM & $15^{\circ} \mathrm{C} / 15$ days & $\begin{array}{l}\text { Pyrene; Naphthalene; } \\
\text { Toluene; Octane; Dodecane; } \\
\text { Hexane }\end{array}$ & $0.1-1 \%$ & Marambio $\left(64^{\circ} 14^{\prime} \mathrm{S}, 56^{\circ} 37^{\prime} \mathrm{W}\right)$ & {$[100]$} \\
\hline $\begin{array}{l}\text { Pseudomonas sp. } \\
\text { FG-4d }\end{array}$ & SBM & $15^{\circ} \mathrm{C} / 15$ days & $\begin{array}{l}\text { Pyrene; Naphthalene; } \\
\text { Toluene; Octane; Dodecane; } \\
\text { Hexane }\end{array}$ & $0.1-1 \%$ & Marambio $\left(64^{\circ} 14^{\prime} \mathrm{S}, 56^{\circ} 37^{\prime} \mathrm{W}\right)$ & {$[100]$} \\
\hline $\begin{array}{l}\text { Pseudomonas sp. } \\
\text { FG-13a }\end{array}$ & SBM & $15^{\circ} \mathrm{C} / 15$ days & $\begin{array}{l}\text { Naphthalene; Octane; } \\
\text { Dodecane; Hexane }\end{array}$ & $0.1-1 \%$ & Marambio $\left(64^{\circ} 14^{\prime} \mathrm{S}, 56^{\circ} 37^{\prime} \mathrm{W}\right)$ & {$[100]$} \\
\hline $\begin{array}{l}\text { Stenotrophomonas sp. } \\
\text { FG-3b2 }\end{array}$ & SBM & $15^{\circ} \mathrm{C} / 15$ days & $\begin{array}{l}\text { Pyrene; Naphthalene; } \\
\text { Toluene; Octane; Dodecane; } \\
\text { Hexane }\end{array}$ & $0.1-1 \%$ & Marambio $\left(64^{\circ} 14^{\prime} \mathrm{S}, 56^{\circ} 37^{\prime} \mathrm{W}\right)$ & {$[100]$} \\
\hline Pedobacter sp. FG-22b & SBM & $15^{\circ} \mathrm{C} / 15$ days & $\begin{array}{l}\text { Pyrene; Naphthalene; } \\
\text { Toluene; Octane; Dodecane; } \\
\text { Hexane }\end{array}$ & $0.1-1 \%$ & Marambio $\left(64^{\circ} 14^{\prime} \mathrm{S}, 56^{\circ} 37^{\prime} \mathrm{W}\right)$ & [100] \\
\hline
\end{tabular}

Table 1: Examples of known hydrocarbon-degrading bacteria from Antarctic soils and information about their hydrocarbon substrates and cultivation.

uncontaminated soil [96]. Furthermore, different cluster formation appeared in each type of contaminated and uncontaminated soil. These data suggest that the soil characteristics and different levels of hydrocarbon contamination affect the distribution of alkane-degrading bacteria [96]. In that study, $85 \%$ of the excised bands were identified as belonging to the Actinobacteria group, whereas the Gamma- and Alphaproteobacteria groups were found in $15 \%$ of the sequenced bands. Due to the important ecological role of this gene group and its sensitivity to contamination, the alkB gene is recommended as a biomarker in this environment [97].

Twenty-eight bacterial strains from Antarctic oil-contaminated soil were studied, and conventional PCR was used to analyze the occurrence, distribution and expression of the biodegradative genes (alkB, ISPa, ndoB, C23DO and todC1/bphA1) [98]. The results showed that the naphthalene dioxygenase gene (ndoB) was commonly found in Pseudomonas sp. The gene ndoB presents evidence of horizontal 
transfer in the Pseudomonas bacterial group and might be originally transferred from outside Antarctica [99]. Of the 28 tested strains, 22 were positive for at least one region of the C23DO gene. Not all microorganisms presented amplification of the alkB gene using a single set of primers, but most of the Rhodococcal isolates inhibited the amplification of a variation of this gene (alkB2). The authors suggested that the differential distribution of these genes in Rhodococcus is related to the types of alkanes present in the soil [98]. The diversity of the alkB gene is far from being completely understood, and many recent studies have revealed high levels of diversity and novel alkB-encoding genes [100-102]. Only two strains showed positive amplification of the bphA1 gene (Coryneform 31/1 and Sphingomonas 35/1), and no strain was positive for amplification of the todC1 gene [98].

Soils with higher and lower contaminations of hydrocarbons were used to evaluate the effects of different hydrocarbon concentrations in bacterial, archaeal and microeukaryotic communities [65]. Through sequencing, conventional PCR and fingerprint techniques, the authors found a higher level of diversity in bacterial and microeukaryotic groups in soils with lower concentrations of hydrocarbons (LC) than in more highly concentrated soils (HC), whereas the archaea group did not exhibit a significant difference between such soils. In the bacterial domain, the analyses revealed the relative abundance of
Proteobacteria, Actinobacteria and Bacteroidetes in HC and LC soils, but sequences related to the Nitrospira, Verrucomicrobia, Chloroflexi, Planctomycetes, and Acidobacteria phyla were only detected in LC soil. At the genus bacterial level, the OUT that presented the highest relative abundance from the $\mathrm{HC}$ soil was affiliated with an uncultured bacterium from candidate division TM7. This bacterial group is frequently described using molecular methods [103], but its possible function in hydrocarbon degradation remains unknown [65]. For the eukaryotic group, ten phyla were found in LC soil, and only four were found in HC soil. Additionally, more than $50 \%$ of the relative abundance observed in HC soil represented fungi, whereas fungi represented $20.85 \%$ of the diversity found in LC soil.

\section{Gene quantifications and abundance}

In an in situ bioremediation experiment, a previous study showed the effect of the biostimulation treatment on the copy numbers of the alkB and rpoB genes over four years using the qPCR technique [83]. The study revealed a relationship between the amounts of alkanes present in the soil and the number of copies of the alkB gene. The addition of fertilizer increased the copy numbers, and the alkane concentration decreased significantly in the first year. Moreover, treatment with less fertilizer was the most effective in the first year and led to a drastic increase in the alkB copy number, but treatment with

\begin{tabular}{|c|c|c|}
\hline Molecular Techniques & Target region and primers/probes used & References \\
\hline T-RFLP & 16S rRNA (27f-1389r) & {$[99,100]$} \\
\hline RFLP & AlkB (alkH1F2/alkH3R) & [56] \\
\hline Dot-Blot & nahH (nahH-F/nahH-R; C23OeF/C23OeR) nahAc (nahAc-F/nahAc-RP/nahAc-RR ;Ac114-F/Ac114-R) alkB (alkB-F/alkB-R) & {$[99,100]$} \\
\hline Southern-blot & nahH (nahH-F/nahH-R; C23OeF/C23OeR) nahAc (nahAc-F/nahAc-RP/nahAc-RR ;Ac114-F/Ac114-R) alkB (alkB-F/alkB-R) & [100] \\
\hline RISA & ITS (1387f/23Sr) & [100] \\
\hline DGGE & 16S rRNA (341F-GC/520R) & [69] \\
\hline DGGE & 16S rRNA (357F-GC/518R) & {$[100]$} \\
\hline DGGE & 16S rRNA (341-F-GC/907-R) & [43] \\
\hline DGGE & 16S rRNA (357F-CG/907R) & [95] \\
\hline DGGE & AlkB (alkH1F2-CG/alkH3R) & {$[56]$} \\
\hline DGGE & 16S rRNA (907R-341F) & [76] \\
\hline DGGE & $\begin{array}{l}\text { Bacterial SSU rRNA (BAC27Fa/BAC518R); Archaeal SSU rRNA (Arch21f/Arch958r; Arch344fa/Arch519r) Microeukaryotic } \\
\text { SSU rRNA (EK7F-EK516R) }\end{array}$ & [39] \\
\hline DGGE & PAH-RHDaGP (PAH-RHDaGP-F ; PAH-RHDaGP-R) & [39] \\
\hline Clone libraries & 16S rRNA (341-F/907-R) & [42] \\
\hline Clone libraries & 16S rRNA (519f-1392r) & [76] \\
\hline Clone libraries & alkB (alk-H1F ; alk-H3R) & [39] \\
\hline Clone libraries & PAH-RHDa(PAH-RHDaGP-F/PAH-RHDaGP-R); PAH-RHDa ${ }_{[G N]}(P A H-R H D a G N-F / P A H-R H D a G N-R)$ & [55] \\
\hline Clone libraries & 16S rRNA (27F/1492R) & [50] \\
\hline Clone libraries & PAH-RHDaGP (PAH-RHDaGP-F ; PAH-RHDaGP-R); xylE (xylE-F/xylE-R) & [69] \\
\hline Real time PCR & 16S rRNA (341F/534R); phoA ( phoA F/phoA R) & [50] \\
\hline Real time PCR & alkB (alkBFd-alkBRd) & [77] \\
\hline Real time PCR & 16S rRNA gene (968F-1401R); PAH-RHDa (GPF-GPR/GNF-GNR) & [69] \\
\hline Sequencing & alkB (alkH3R) & [56] \\
\hline Conventional PCR & $\begin{array}{l}\text { alkB (alk-H1F/alk-H3R); PAH-RHDa(PAH-RHDaGP-F/PAH-RHDaGP-R); PAH-RHDaGN (PAH-RHDaGN-F/PAH- } \\
\text { RHDaGN-R); bamA (BamSP9F/BamASP1R); assA/bssA (ass/bssF/ass/bssR) }\end{array}$ & [39] \\
\hline Conventional PCR & PAH-RHDa (GPF/GPR; GNF/GNR); xylE (xylE-F/xylE-R) bph (bphC-F/bphC-R) & [69] \\
\hline Conventional PCR & $\begin{array}{l}\text { alk (L-alkB/R-alkB; L-alkB870G/R-alkB870G; L-TS2S/L-TS2Smod/L-TS2Smod2; R-deg1RE/R-deg1RE2; RH L-alkB1/RH } \\
\text { R-alkB1; RH L-alkB2/RH R-alkB2; RH L-alkB194/RH R-alkB194; (Ac) alkM-F/(Ac) alkM-R); ndoB (L-ndoB/R-ndoB); C23DO } \\
\text { (L-cat238/R-cat238; xylEb-F/xylEb-R; cat2,3 1a-F/cat2,3 6a-R); tod (todC1-F/todC1-R); bph (bphA1-F/bphA1-R) }\end{array}$ & [72] \\
\hline Competitive PCR & cndoB (L-ndoB/R-cndoB) & [72] \\
\hline RT-PCR & alkB2 (RH L-alkB2/RH R-alkB2); C23DO (cat2,3 1a-F/cat2,3 6a-R); ndoB (L-ndoB/R-ndoB) & [72] \\
\hline $\begin{array}{l}\text { Operational Protein } \\
\text { Families (ORFs) analysis }\end{array}$ & PAH-RHDa(PAH-RHDaGP-F/PAH-RHDaGP-R); PAH-RHDa ${ }_{[G N]}$ (PAH-RHDaGN-F/PAH-RHDaGN-R) & [55] \\
\hline
\end{tabular}

Table 2: Molecular techniques and primers or probes used in bioremediation of Antarctic soil studies. 
a high concentration of fertilizer resulted in the highest degradation level. Four years later, the copy number of the alkB gene increased only in the control treatment (chronically contaminated), which was likely due to the remaining contamination [83], and the bioremediation process continued to have an effect when the alkane level was driven to almost zero.

Hydrocarbon gene quantification through qPCR also revealed the presence of PAH dioxygenase (PAH-RHD $\alpha$ ) near Syowa station [95]. The evaluated soil showed evidence of additional effects from human activities compared with other pristine soils analyzed in the same study, in which copies of those genes were not found. The same result was found in another study [104] that analyzed soil samples from King George island that were contaminated and non-contaminated by hydrocarbons. Thus, PAH-RHDa-encoding genes appear to be related to the levels of anthropogenic and oil contamination impact $[83,104]$. Furthermore, NidA3-like sequences from Mycobacterium species were the most abundant ORFs found in the PAH-RHDa [GP] libraries [104]. NidA3 from Mycobacterium has been shown to be responsible for the transformation of several aromatic hydrocarbon compounds [105].

In a microcosm experiment using soil from the Cape Burks area, the effect of nutrient and diesel oil addition was demonstrated based on copy numbers of the phoA gene and the 16S rRNA gene [106]. The results showed that the $16 \mathrm{~S}$ rRNA copy number nearly doubled for all treatments after 30 days at $4^{\circ} \mathrm{C}$, but the major increase was observed with nutritional input. The greatest increase in the phoA gene occurred in soils without diesel oil addition, which suggested that diesel addition was toxic to the microbial community [106]. Bacterial phylogenetic groups belonging to Actinobacteria, Proteobacteria, Verrucomicrobia, Firmicutes, Chloroflexi, Planctomycetes, Bacteroidetes, and Gemmatimonadetes were found in intact, nutritionally supplemented, and diesel-contaminated soil. Libraries from intact Antarctic soil demonstrated the predominance of the Actinobacteria phylum (74.7\%) (composed mostly of Pseudonocardia species), whereas nutritional addition resulted in a shift towards the Actinobacteria phylum (95.6\%) (composed mostly of Arthrobacter species). In diesel-contaminated soils, the Proteobacteria phylum (37.5\%) (mostly Alphaproteobacteria and Phyllobacterium species) was predominant [106].

\section{Conclusions and Perspectives}

The Antarctic continent is known for its pristine condition and extreme life conditions. For these reasons, the continent has drawn much military, political and scientific interest from various nations. Currently, the main reason for human activities in Antarctica is the development of research, and for this purpose, the installation of research stations and human presence in the continent is indispensable. The humans on the continent demand few necessities, but energy generation is one of them. In addition, fishing and tourist ships add to the number of ways that humans gain access to the region.

Thus, the risks involved in the manipulation, transport and storage of fuel oil used in energy generation are always present. Several accidental spills have occurred in the Antarctic continent, but to date, there has been no strategy that can be rapidly implemented to promote efficient environmental recovery. Generally, the accidents occurring in the continent were treated as minor issues, and the contamination has become chronic. Despite several publications on this topic, bioremediation in a cold environment is generally considered a difficult task, but many scientific studies from this region have shown that is possible to perform bioremediation in the Antarctic continent. It is generally agreed that the bioremediation process should be applied following physical cleanup methods to achieve a more efficient cleanup.

As in another contaminated areas, the bioremediation process performed in Antarctic soil is site- and contaminant-specific and occurs with greater efficiency under aerobic conditions. The necessary prior studies of contaminated sites can be performed ex situ through soil analysis, molecular screening and microbial isolation, as well as preliminary studies involving microcosms. However, subsequent analyses involving mesocosms and macrocosms are better performed in situ, once the environmental conditions have stabilized, to ensure the accuracy of the results. Due to geographic issues and difficult access to the continent, bioremediation application on a large scale should be performed in situ, unless there is a nearby structure at the contaminated site that allows the transport of the contaminated soil to an ex situ treatment site. In that case, treatment ex situ is indicated due to the improved possibilities for controlling physical factors (e.g., temperature).

The studies conducted to date reveal that despite our knowledge of the microbial strains that can degrade hydrocarbons in Antarctic soils, studies regarding isolation and characterization have become rare in the last few years. Moreover, there are no studies on the bioremediation process in soils from the core of the continent, only from the shore regions. This difference is likely due to the great number of research stations present in the island and shore regions (Figure 1), but the increasing number of human activities in the middle of the Antarctic continent will likely result in more risks in this region.

Based on the knowledge acquired to date, it is possible to suggest certain procedures for Antarctic activities that involve the utilization of oils. Maintenance activities such as refueling, the cleanup of oil tanks and the transport of oils could be performed in or near the winter period (with snow on the ground) because the snow can serve as a physical barrier by containing the contaminant and thus blocking oil penetration into the soil, acting as an absorbent. In contrast, bioremediation application could be preferentially performed in the summer, due to the higher temperature, but before the thaw period, when the unfrozen ice can spread the oil to more sensitive regions and the nutrients can be disturbed. Thus, bioremediation processes in Antarctic soils are very promising but should be performed properly, considering the environmental seasons and recuperative actions that must be performed as soon as possible after the spill. Furthermore, it is urgently necessary to create guidelines for research station activities that involve the management of oils and procedures in future accidents.

\section{Acknowledgements}

The authors would like to thank the Conselho Nacional de Desenvolvimento Científico e Tecnológico (CNPq), Fundação de Amparo à Pesquisa do Estado do Rio de Janeiro (FAPERJ) and Coordenação de Aperfeiçoamento de Pessoal de Nível Superior (CAPES).

\section{References}

1. Atlas RM (1975) Effects of temperature and crude oil composition on petroleum biodegradation. Appl Microbiol 30: 396-403

2. Jobson A, Cook FD, Westlake DW (1972) Microbial utilization of crude oil. App Microbiol 23: 1082-1089.

3. Atlas RM (1991) Microbial hydrocarbon degradation-bioremediation of oil spills J Chem Technol Biotechnol 52: 149-156.

4. Cho YG, Rhee S, Lee S (2000) Effect of soil moisture on bioremediation of chlorophenol-contaminated soil. Management 915-919.

5. Yang SZ, Jin HJ, Wei Z, He RX, Ji YJ, et al. (2009) Bioremediation of Oil Spills in Cold Environments: A Review. Pedosphere 19: 371-381.

6. Robles-González IV, Fava F, Poggi-Varaldo HM (2008) A review on slurry 
bioreactors for bioremediation of soils and sediments. Microb Cell Fact 7: 5 .

7. Sierra-Garcia I, Oliveira V de (2013) Microbial Hydrocarbon Degradation: Efforts to Understand Biodegradation in Petroleum Reservoirs. In: Chamy DR (ed.), Biodegradation - Engineering and Technology. InTech: 47-72.

8. Van Hamme JD, Singh A, Ward OP (2003) Recent advances in petroleum microbiology. Microbiol Mol Biol Rev 67: 503-549.

9. Rojo F (2009) Degradation of alkanes by bacteria. Environ Microbiol 11: 24772490.

10. Ismail W, Gescher J (2012) Epoxy Coenzyme A Thioester pathways for degradation of aromatic compounds. Appl Environ Microbiol 78: 5043-5051.

11. Vilchez-Vargas R, Junca H, Pieper DH (2010) Metabolic networks, microbial ecology and 'omics' technologies: towards understanding in situ biodegradation processes. Environ Microbiol 12: 3089-3104.

12. Foght $\mathrm{J}$ (2008) Anaerobic biodegradation of aromatic hydrocarbons: pathways and prospects. J Mol Microbiol Biotechnol 15: 93-120.

13. Tian Y, Luo YR, Zheng TL, Cai LZ, Cao XX, et al. (2008) Contamination and potential biodegradation of polycyclic aromatic hydrocarbons in mangrove sediments of Xiamen, China. Mar Pollut Bull 56: 1184-1191.

14. Bargagli R (2008) Environmental contamination in Antarctic ecosystems. Sc Total Environ 400: 212-226.

15. Aislabie J, Saul DJ, Foght JM (2006) Bioremediation of hydrocarboncontaminated polar soils. Extremophiles 10: 171-179.

16. Aislabie J, Mcleod M, Fraser R (1998) Potential for biodegradation of hydrocarbons in soil from the Ross Dependency, Antarctica. Appl Microbiol $49: 210-214$

17. Coulon F, Pelletier E, St Louis R, Gourhant L, Delille D (2004) Degradation of petroleum hydrocarbons in two sub-antarctic soils: influence of an oleophilic fertilizer. Environ Toxicol Chem 23: 1893-1901.

18. Yergeau E, Arbour M, Brousseau R, Juck D, Lawrence JR, et al. (2009) Microarray and real-time PCR analyses of the responses of high-arctic soil bacteria to hydrocarbon pollution and bioremediation treatments. Appl Environ Microbiol 75: 6258-6267.

19. Aislabie J, Foght J, Saul D (2000) Aromatic hydr ocarbon-degrading bacteria from soil near Scott Base, Antarctica. Polar Biol 23: 183-188.

20. Aislabie JM, Balks MR, Foght JM, Waterhouse EJ (2004) Hydrocarbon spills on Antarctic soils: effects and management. Environ Sci Technol 38: 1265-1274.

21. Aislabie JM, Jordan S, Barker GM (2008) Relation between soil classification and bacterial diversity in soils of the Ross Sea region, Antarctica Geoderma 144: 9-20.

22. Antarctic Treaty Consultative Parties (1991) Protocol on environmental protection to the antarctic treaty, Her Majesty's Stationery Office, London.

23. Arnold RJ, Convey P, Hughes KA, Wynn-Williams DD (2003) Seasonal periodicity of physical factors, inorganic nutrients and microalgae in Antarctic fellfields. Polar Biol 26: 396-403.

24. Atlas RM (1981) Microbial degradation of petroleum hydrocarbons: an environmental perspective. Microbiol Rev 45: 180-209.

25. Atlas RM (1986) Fate of Petroleum Pollutants in Arctic Ecosystems. Water Sci Technol 18: 59-67.

26. Baraniecki CA, Aislabie J, Foght JM (2002) Characterization of Sphingomonas sp. Ant 17, an aromatic hydrocarbon-degrading bacterium isolated from Antarctic soil. Microb Ecol 43: 44-54.

27. Bej AK, Saul D, Aislabie J, (2000) Cold-tolerant alkane-degrading Rhodococcus species from Antarctica. Polar Biol 23: 100-105.

28. Belhaj A, Desnoues N, Elmerich C (2002) Alkane biodegradation in Pseudomonas aeruginosa strains isolated from a polluted zone: identification of alkB and alkB-related genes. Res Microbiol 153: 339-344.

29. Bicca FC, Fleck LC, Ayub MAZ (1999) Production of biosurfactant by hydrocarbon degrading Rhodococcus ruber and Rhodococcus erythropolis. Rev Microbiol 30: 231-236.

30. Bressler DC, Gray MR (2003) Transport and Reaction Processes in Bioremediation of Organic Contaminants. 1. Review of Bacterial Degradation and Transport. Int J Chem React 1.
31. Brooijmans RJ, Pastink MI, Siezen RJ (2009) Hydrocarbon-degrading bacteria: the oil-spill clean-up crew. Microb Biotechnol 2: 587-594

32. Burns K, Codi S, Duke N, (2000) Gladstone, Australia Field Studies: Weathering and Degradation of Hydrocarbons in Oiled Mangrove and Salt Marsh Sediments With and Without the Application of an Experimental Bioremediation Protocol. Mar Pollut Bull 41: 392-402.

33. Cary SC, McDonald IR, Barrett JE, Cowan DA (2010) On the rocks: the microbiology of Antarctic Dry Valley soils. Nat Rev Microbiol 8: 129-138.

34. Chugunov VA (2000) Development and Application of a Liquid Preparation with Oil-Oxidizing Bacteria. 36: 577-581.

35. Confalonieri F, Sommer S (2011) Bacterial and archaeal resistance to ionizing radiation. J Phys Conf Ser 261: 1.

36. Cosgrove L, McGeechan PL, Handley PS, Robson GD (2010) Effect of biostimulation and bioaugmentation on degradation of polyurethane buried in soil. Appl Environ Microbiol 76: 810-819

37. Coulon F, Delille D (2003) Effects of Biostimulation on Growth of Indigenous Bacteria in Sub-Antarctic Soil Contamined with Oil Hydrocarbons. Oil Gas Sci. Technol 58: 469-479.

38. Crockett AB, White GJ (2003) Mapping sediment contamination and toxicity in Winter Quarters Bay, McMurdo Station, Antarctica. Environ Monit Assess 85 257-275.

39. Cury JC (2014) Microbial diversity and hydrocarbon depletion in low and high diesel-polluted soil samples from Keller Peninsula, South Shetland Islands. Antarct Sci 11: 1-11.

40. Delille D, Coulon F (2008) Comparative mesocosm study of biostimulation efficiency in two different oil-amended sub-antarctic soils. Microb Ecol 56: 243-252.

41. Delille D, Coulon F, Pelletier E (2004) Biostimulation of natural microbia assemblages in oil-amended vegetated and desert sub-Antarctic soils. Microb Ecol 47: 407-415.

42. Dias RL (2014) Hydrocarbon removal and bacterial community structure in on-site biostimulated biopile systems designed for bioremediation of dieselcontaminated Antarctic soil. Polar Biol 38, 677-687.

43. Dias RL (2012) Bioremediation of an aged diesel oil-contaminated Antarctic soil: Evaluation of the "on site" biostimulation strategy using different nutrient sources. Int Biodeterior Biodegrad 75: 96-103.

44. Doran PT, Priscu JC, Lyons WB, Walsh JE, Fountain AG, et al. (2002) Antarctic climate cooling and terrestrial ecosystem response. Nature 415: 517-520.

45. Eckford R, Cook FD, Saul D, Aislabie J, Foght J (2002) Free-living heterotrophic nitrogen-fixing bacteria isolated from fuel-contaminated antarctic soils. App Environ Microbiol 68: 5181-5185.

46. Filler DM (2006) Advances in engineered remediation for use in the Arctic and Antarctica. Polar Rec 42: 111

47. Finegold L (1996) Molecular and biophysical aspects of adaptation of life to temperatures below the freezing point. Adv Sp Res 18: 87-95.

48. Ghazali FM, Rahman R, Salleh A, Basri M (2004) Biodegradation of hydrocarbons in soil by microbial consortium. Int Biodeterior Biodegradation 54: 61-67.

49. Guibert LM, Loviso CL, Marcos MS, Commendatore MG, Dionisi HM, et al. (2012) Alkane biodegradation genes from chronically polluted subantarctic coastal sediments and their shifts in response to oil exposure. Microb Ecol 64: 605-616.

50. Han J, Jung J, Hyun S, Park H, Park W (2012) Effects of nutritional input and diesel contamination on soil enzyme activities and microbial communities in Antarctic soils. J Microbiol 50: 916-924.

51. Harangozo S (2006) Atmospheric circulation impacts on winter maximum sea ice extent in the west Antarctic Peninsula region (1979-2001). Geophys Res Lett 33: 2001-2004.

52. Horowitz NH, Bauman AJ, Cameron RE, Geiger PJ, Hubbard JS, et al. (1969) Sterile soil from Antarctica: organic analysis. Science 164: 1054-1056.

53. Hugenholtz P, Tyson GW, Webb RI, Wagner AM, Blackall LL (2001) Investigation of candidate division TM7, a recently recognized major lineage of the domain Bacteria with no known pure-culture representatives. Appl Environ Microbiol 67: 411-419. 
54. Jacques RJ, Okeke BC, Bento FM, Teixeira AS, Peralba MC, et al. (2008) Microbial consortium bioaugmentation of a polycyclic aromatic hydrocarbons contaminated soil. Bioresour Technol 99: 2637-2643.

55. Jurelevicius D, Alvarez VM, Peixoto R, Rosado, AS, Seldin L (2012) Bacterial polycyclic aromatic hydrocarbon ring-hydroxylating dioxygenases (PAH-RHD) encoding genes in different soils from King George Bay, Antarctic Peninsula. Appl Soil Ecol 55: 1-9.

56. Jurelevicius D, Cotta SR, Peixoto R, Rosado AS, Seldin L (2012) Distribution of alkane-degrading bacterial communities in soils from King George Island, Maritime Antarctic. Eur J Soil Biol 51: 37-44.

57. Kennicutt MC (2003) Spatial and Temporal Scales of Human Disturbance McMurdo Station. Crary Science Lecture Series, McMurdo Station, Antarctica.

58. Kim D, Kim YS, Kim SK, Kim SW, Zylstra GJ, et al. (2002) Monocyclic aromatic hydrocarbon degradation by Rhodococcus sp. strain DK17. Appl Environ Microbiol 68: 3270-3278

59. Kim E, Aversano PJ, Romine MF, Schneider RP, Zylstra GJ (1996) Homology between genes for aromatic hydrocarbon degradation in surface and deepsubsurface Sphingomonas strains. Appl Environ Microbiol 62: 1467-1470.

60. Korda A, Santas P, Tenente A, Santas R (1997) Petroleum hydrocarbon bioremediation: sampling and analytical techniques, in situ treatments and commercial microorganisms currently used. Appl Microbiol Biotechnol 48: 677-686.

61. Kuhn E, Bellicanta GS, Pellizari VH (2009) New alk genes detected in Antarctic marine sediments. Environ Microbiol 11: 669-673.

62. Kweon O (2010) Substrate specificity and structural characteristics of the novel Rieske nonheme iron aromatic ring-hydroxylating oxygenases NidAB and NidA3B3 from Mycobacterium vanbaalenii PYR-1. M Bio 1: 9-14.

63. Lee M, Kim MK, Singleton I, Goodfellow M, Lee ST (2006) Enhanced biodegradation of diesel oil by a newly identified Rhodococcus baikonurensis EN3 in the presence of mycolic acid. J Appl Microbiol 100: 325-333.

64. Li H, Zhao Q, Boufadel MC, Venosa AD (2007) A universal nutrient application strategy for the bioremediation of oil-polluted beaches. Mar Pollut Bull 54: 1146-1161.

65. Ma Y, Wang L, Shao Z (2006) Pseudomonas, the dominant polycyclic aromatic hydrocarbon-degrading bacteria isolated from Antarctic soils and the role of large plasmids in horizontal gene transfer. Environ Microbiol 8: 455-465.

66. Manfio GP (2002) Avaliação do estado atual do conhecimento sobre a diversidade microbiana no Brasil. In: Lewinsohn TM, Prado PI (eds.), Biodiversidade Brasileira: Síntese Do Estado Atual Do Conhecimento. São Paulo: 151-153.

67. Margesin R, Schinner F (1999) Review Biological decontamination of oil spills in cold environments. Chem. Technol 389: 381-389.

68. Margesin R, Schinner F (2001) Biodegradation and bioremediation of hydrocarbons in extreme environments. Appl Microbiol Biotechnol 56: 650-663.

69. Muangchinda C, Chavanich S, Viyakarn V, Watanabe K, Imura S, et al. (2015) Abundance and diversity of functional genes involved in the degradation of aromatic hydrocarbons in Antarctic soils and sediments around Syowa Station. Environ Sci Pollut Res Int 22: 4725-4735.

70. Negri A, Marshall P (2009) TBT contamination of remote marine environments: ship groundings and ice-breakers as sources of organotins in the Great Barrier Reef and Antarctica. J Environ Manage 90 Suppl 1: S31-40.

71. Nie Y, Chi CQ, Fang H, Liang JL, Lu SL, et al. (2014) Diverse alkane hydroxylase genes in microorganisms and environments. Sci Rep 4: 4968.

72. Panicker G, Mojib N, Aislabie J, Bej AK (2010) Detection, expression and quantitation of the biodegradative genes in Antarctic microorganisms using PCR. Antonie Van Leeuwenhoek 97: 275-287.

73. Peat HJ, Clarke A, Convey P (2007) Diversity and biogeography of the Antarctic flora. J Biogeogr 34: 132-146.

74. Pérez-de-Mora A, Engel M, Schloter M (2011) Abundance and diversity of $n$-alkane-degrading bacteria in a forest soil co-contaminated with hydrocarbons and metals: a molecular study on alkB homologous genes. Microb Ecol 62: 959-972

75. Poland JS, Riddle MJ, Zeeb BA (2003) Contaminants in the Arctic and the Antarctic: a comparison of sources, impacts, and remediation options. Polar $\operatorname{Rec}$ (Gr. Brit) 39: 369-383.
76. Powell SM, Bowman JP, Snape I, Stark JS (2003) Microbial community variation in pristine and polluted nearshore Antarctic sediments. FEMS Microbiol Ecol 45: $135-145$.

77. Powell SM, Ferguson SH, Bowman JP, Snape I (2006) Using real-time PCR to assess changes in the hydrocarbon-degrading microbial community in Antarctic soil during bioremediation. Microb Ecol 52: 523-532.

78. Rawe J, Krietemeyer S, Meagher-Hartzell E (1993) Guide for Conducting Treatability Studies Under CERCLA: Biodegradation Remedy Selection, US Environmental Protection Agency, Washington DC.

79. Rayner JL, Snape I, Walworth JL, Harvey PM, Ferguson SH (2007) Petroleumhydrocarbon contamination and remediation by microbioventing at subAntarctic Macquarie Island. Cold Reg Sci Technol 48: 139-153.

80. Röling WF, van Verseveld HW (2002) Natural attenuation: what does the subsurface have in store? Biodegradation 13: 53-64.

81. Ruberto LAM, Vazquez S, Lobalbo A, Mac Cormack WP (2005) Psychrotoleran hydrocarbon-degrading Rhodococcus strains isolated from polluted Antarctic soils. Antarct Sci 17: 47-56.

82. Ruberto L, Dias R, Lo Balbo A, Vazquez SC, Hernandez EA, et al. (2009) Influence of nutrients addition and bioaugmentation on the hydrocarbon biodegradation of a chronically contaminated Antarctic soil. J Appl Microbiol 106: $1101-1110$

83. Ruberto L, Vazquez S, Mac WP (2008) Bacteriology of extremely cold soils exposed to hydrocarbon pollution. In: Microbiology of Extreme Soils: 247-274.

84. Ruberto L, Vazquez SC, Cormack WP, Mac (2003) Effectiveness of the natural bacterial flora, biostimulation and bioaugmentation on the bioremediation of a hydrocarbon contaminated Antarctic soil. Int Biodeterior. Biodegradation 52 115-125.

85. Santos HF, Carmo FL, Paes JES, Rosado AS, Peixoto RS (2010) Bioremediation of Mangroves Impacted by Petroleum. Water, Air, Soil Pollut 216: 329-350.

86. Saul DJ, Aislabie JM, Brown CE, Harris L, Foght JM (2005) Hydrocarbon contamination changes the bacterial diversity of soil from around Scott Base, Antarctica. FEMS Microbiol Ecol 53: 141-155.

87. Shukor MY, Gusmanizar N, Ramli J, Shamaan NA, MacCormack WP, et al. (2009) Isolation and characterization of an acrylamide-degrading Antarctic bacterium. J Environ Biol 30: 107-112.

88. Shukor MY, Hassan NA, Jusoh AZ, Perumal N, Shamaan NA, et al. (2009) Isolation and characterization of a Pseudomonas diesel-degrading strain from Antarctica. J Environ Biol 30: 1-6.

89. Siron R, Pelletier E, Brochu C (1995) Environmental factors influencing the biodegradation of petroleum hydro- carbons in cold seawater. Arch Environ Contam Toxicol 28: 406-416.

90. Smith JJ, Tow LA, Stafford W, Cary C, Cowan DA (2006) Bacterial diversity in three different Antarctic Cold Desert mineral soils. Microb Ecol 51: 413-421.

91. Smith RC, Prézelin BB, Baker KS, Bidigare RR, Boucher NP, et al. (1992) Ozone depletion: ultraviolet radiation and phytoplankton biology in antarctic waters. Science 255: 952-959.

92. Snape I, Ferguson SH, Harvey PM, Riddle MJ (2006) Investigation of evaporation and biodegradation of fuel spills in Antarctica: II-extent of natural attenuation at Casey Station. Chemosphere 63: 89-98.

93. Snape I, Riddle MJ, Filler DM, Williams PJ (2003) Contaminants in freezing ground and associated ecosystems: key issues at the beginning of the new millennium. Polar Rec (Gr. Brit) 39: 291-300.

94. So CM, Phelps CD, Young LY (2003) Anaerobic transformation of alkanes to fatty acids by a sulfate-reducing bacterium, strain $\mathrm{Hxd} 3$. Appl Environ Microbiol 69: 3892-3900.

95. Stallwood B, Shears J, Williams PA, Hughes KA (2005) Low temperature bioremediation of oil-contaminated soil using biostimulation and bioaugmentation with a Pseudomonas sp. from maritime Antarctica. J Appl Microbiol 99: 794-802.

96. Tarnocai C, Campbell IB (2002) Soils of the polar regions. In: Dekker M (ed.), Encyclopedia of Soil Science. Lal R, New York: 1018-1021.

97. Thomassin-Lacroix EJ, Eriksson M, Reimer KJ, Mohn WW (2002) Biostimulation and bioaugmentation for on-site treatment of weathered diesel fuel in Arctic soil. Appl Microbiol Biotechnol 59: 551-556. 
98. Tosi S, Onofri S, Brusoni M, Zucconi L, Vishniac H (2005) Response of Antarctic soil fungal assemblages to experimental warming and reduction of UV radiation. Polar Biol 28: 470-482.

99. Vázquez S, Nogales B, Ruberto L, Hernández E, Christie-Oleza J, et al. (2009) Bacterial community dynamics during bioremediation of diesel oil-contaminated Antarctic soil. Microb Ecol 57: 598-610.

100.Vázquez S (2013) Characterization of bacterial consortia from dieselcontaminated Antarctic soils: Towards the design of tailored formulas for bioaugmentation. Int Biodeterior Biodegradation 77: 22-30.

101. Viñas M, Grifoll M, Sabaté J, Solanas AM (2002) Biodegradation of a crude oil by three microbial consortia of different origins and metabolic capabilities. J Ind Microbiol Biotechnol 28: 252-260.

102. Vishniac H (1993) Soil Microbiology. In: Friedmann El (ed.), Antarctic Microbiology. Wiley-Liss, New York: 297-341.

103. Vogel TM (1996) Bioaugmentation as a soil bioremediation approach. Curr Opin Biotechnol 7: 311-316.

104. Wagner M, Loy A, Nogueira R, Purkhold U, Lee N, et al. (2002) Microbial community composition and function in wastewater treatment plants. Antonie Van Leeuwenhoek 81: 665-680.

105.Wang SJ, Wang X, Lu GL, Wang QH, Li FS, et al. (2011) [Bioremediation of petroleum hydrocarbon-contaminated soils by cold-adapted microorganisms: research advance]. Ying Yong Sheng Tai Xue Bao 22: 1082-1088.

106. Warhurst AM, Fewson CA (1994) Biotransformations catalyzed by the genus Rhodococcus. Crit Rev Biotechnol 14: 29-73.

107. Watanabe K (2001) Microorganisms relevant to bioremediation. Curr Opin Biotechnol 12: 237-241.

108. Watanabe K, Hamamura N (2003) Molecular and physiological approaches to understanding the ecology of pollutant degradation. Curr Opin Biotechnol 14: 289-295.

109. Whyte LG, Slagman SJ, Pietrantonio F, Bourbonnière L, Koval SF, et al. (1999) Physiological adaptations involved in alkane assimilation at a low temperature by Rhodococcus sp. strain Q15. Appl Environ Microbiol 65: 2961-2968.

110. Whyte LG, Bourbonniére L, Greer CW (1997) Biodegradation of petroleum hydrocarbons by psychrotrophic Pseudomonas strains possessing both alkane (alk) and naphthalene (nah) catabolic pathways. Appl Environ Microbiol 63: 3719-3723.

111. Wood TK (2008) Molecular approaches in bioremediation. Curr Opin Biotechnol 19: 572-578.

112. Xu Y, Lu M (2010) Bioremediation of crude oil-contaminated soil: comparison of different biostimulation and bioaugmentation treatments. $\mathrm{J}$ Hazard Mater 183: 395-401.

113. Yakimov MM, Giuliano L, Bruni V, Scarfi S, Golyshin PN (1999) Characterization of antarctic hydrocarbon-degrading bacteria capable of producing bioemulsifiers. New Microbiol 22: 249-256.

114. Yergeau E, Newsham KK, Pearce DA, Kowalchuk GA (2007) Patterns of bacterial diversity across a range of Antarctic terrestrial habitats. Environ Microbiol 9: 2670-2682.

115. Zanaroli G, Di Toro S, Todaro D, Varese GC, Bertolotto A, et al. (2010) Characterization of two diesel fuel degrading microbial consortia enriched from a non acclimated, complex source of microorganisms. Microb Cell Fact 9: 10.

116. Zhang H, Sekiguchi $Y$, Hanada S, Hugenholtz P, Kim H, Kamagata $Y$, Nakamura K (2003) Gemmatimonas aurantiaca gen. nov., sp. nov., a Gramnegative, aerobic, polyphosphate-accumulating micro-organism, the first cultured representative of the new bacterial phylum Gemmatimonadetes phy Nov Int J Syst Evol Microbiol 53: 1155-1163. 